\title{
インフルエンザ
}

\author{
渡理 英二 \\ 日本医科大学微生物学・兔疫学教室
}

Influenza V irus Infection

Eiji Watari

Department of Microbiology and Immunology, Nippon Medical School

トリ由来のインフルエンザウイルスが直接ヒトに感 染し, 死亡者を出した 1997 年の新型インフルエンザ ウイルス A 香港 H $5 \mathrm{~N}$ 1の出現が発端となって, インフルエンザか種を越えた感染症として認識されて きた ${ }^{1}$. .た一方でインフルエンザの流行は，光の年の 超過死亡率を高めることが知られている．弚の要因 は乳幼児や高齢者, 免疫抑制患者への感染であり， 产れに対する感染防御は特に重要な問題である.关こで 今回はインフルエンザウイルスが感染性を発揮する ためには, ウイルス表面にある赤血球凝集素 (HA) 分子の開裂構造が重要であるとの観点から光のメカ ニズムと，個体を越えた階層間におけるダイナミズムの 理解と監視行動がウイルス感染防御に重要であるとの 2つの観点から概説する。

\section{[1] 細胞レベルにおける感染}

1. インフルエンザウイルスは気道にある蛋白質分 解酵素の働きで感染性を獲得する。

ヒトインフルエンザウイルスは光の内部構造により A，B，C 型に分類され (表 1)，図1に示すように表 面に赤血球凝集素 (HA) とノイラミニダーゼ (NA) をもつ.このうち HA は細胞表層のシアル酸をもつ ラクト系糖鎖構造を含む受容体 (レセプター) に結合 する ${ }^{2}$.しかしながらシアル酸をもつ糖鎖構造物質は 全身に分布しており，気道上皮への感染は受容体の問 題だけでは説明がつかない，通常，ヒ卜咽頭から分離 されたインフルエンザウイルスは不活性化した状態に あり，イ又腎臓由来 MDCK 細胞に直接接種しても感 染性を示さないが, 培養液にトリプシンなど蛋白質分

Correspondence to $\mathrm{Eiji}$ Watari, Department of Microbiology and Immunology, Nippon Medical School, 1-1-5 Sendagi, Bunky o-ku, T oky o 113-8603, Japan Journal Website (http://www.nms.ac.jp/jnms/)
解酵素を加えると感染性を獲得するようになる．この ことはウイルスが蛋白質分解酵素により活性化しな いと，気道上皮細胞には感染できないことを意味する． 最近，気道に存在する種々の蛋白質分解酵素がウイルス 外皮 $\mathrm{HA}$ 分子の一部を開裂させることにより，ウイ ルスを不活性型から活性型に変化させることが明らか になってきた(図 2) . これらのなかには, 図 2に示す ように鼻腔, 気道に存在する細菌や宿主に由来するも のなど多くの蛋白質分解酵素の関与が知られている ${ }^{3}$. このことは細菌に対する抗生物質の適切な投与方法 の検討や蛋白質分解酵素インヒビターなどによるイン フルエンザ感染治療の可能性があり今後の研究課題と なっている .

2. HA 分子の開裂はウイルス遺伝子を細胞質内に 挿入するのに必須である .

それではなぜHA は開裂しなければならないか． まず，インフルエンザウイルスや麻疹ウイルスなどの 膜 (エンベロープ) を持つウイルスは細胞質内にウイ ルス遺伝子を侵入させる必要がある. 光の場合ウイルス 遺伝子はウイルス膜と細胞膜を通り抜けなければな らない，关こでウイルスは細胞膜とウイルス膜を融合 させ，产の遺伝子 (V-RNA) を細胞質に侵入させる . この融合にHA の開裂が必要なのである. 谷の機構 を図 3 と図 4 に示す。

A . 3量体 HA の単量体部分の構造 (図 3-A)

B . インフルエンザウイルス外被 $\mathrm{HA}$ 分子の一部 が上記の蛋白質分解酵素により切断, 開裂された状態 (図 3-A，B)でベジクルとして細胞内に取り込まれる (図 4-1).

C . 光のベジクルは酸性 $\mathrm{pH}$ のエンドゾームと融合 する (図 4-2) (図 3-D).

D ベジクル内か酸性状態になると HA 3 量体の HA 1サブユニットは花が開くように広がる (図 3-C) .

$\mathrm{E}$. 膜に親和性の高い踈水基を持った $\mathrm{HA} 2$ 2サブユ 
表1 ヒトインフルエンザウイルスの分類

\begin{tabular}{|c|c|c|c|}
\hline 型 & A & B & C \\
\hline 分離年 & 1993 & 1940 & 1947 \\
\hline 流行形式 & pandemic, epidemic, endemic & epidemic, endemic & endemic \\
\hline HA 亜型 & $\begin{array}{l}\text { 1-3型 }(\text { ヒト }) \\
\text { 1一15型 }(\text { トリ })\end{array}$ & なし & なし \\
\hline NA 亜型 & $\begin{array}{l}1-2 \text { (ヒト) } \\
1-9 \text { 型 (トリ) }\end{array}$ & なし & なし \\
\hline 潜伏期 & 1〜 4日 & 1〜 4日 & 感染実験で4日 \\
\hline 発熱 & $38 \sim 40$ 度 & $38 \sim 40$ 度 & ほとんどない \\
\hline 呼吸器症状 & m & $H \sim m$ & $+\sim+$ \\
\hline 全身症状 & m & $\# \sim m$ & $+\sim$ \\
\hline 合併症 & 脳炎, クループ, CNS & Reye症候群 & なし \\
\hline 赤血球凝集性 & ニワトリ，モルモット & ニワトリ & \\
\hline 自然宿主 & $\begin{array}{l}\text { ヒト,ブタ, ニワトリ } \\
\text { ウマなど多くの脊椎動物 }\end{array}$ & 主にヒト & ヒトのみ \\
\hline 増殖細胞 & MDCK (イヌ腎臓細胞) & MDCK & 7ー9日の羊膜腔 \\
\hline
\end{tabular}

(植竹久雄, ウイルス学第 3 版から改変)

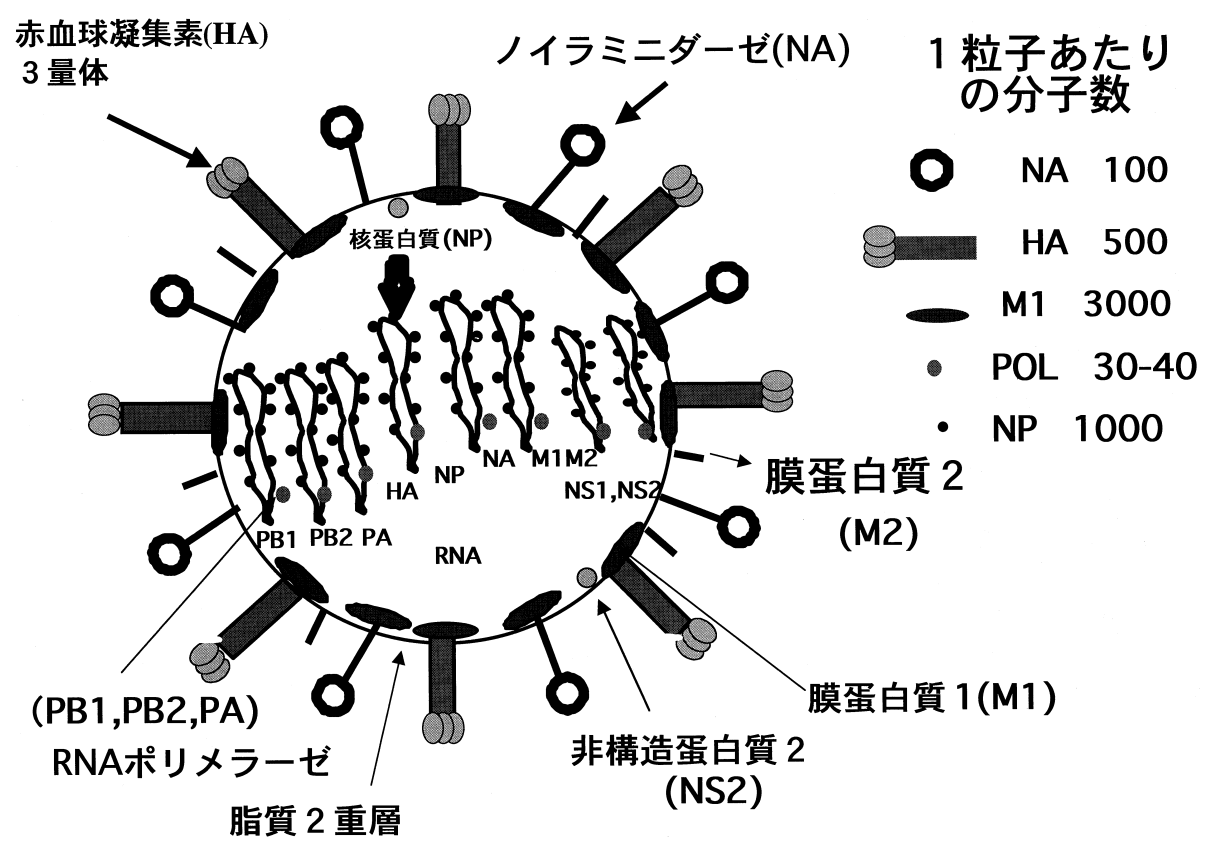

図 1 インフルエンザウイルスの構造

ニットの $\mathrm{N}$ 末端が表出し，ウイルス膜と細胞側エン ドゾーム膜が融合する (図 3-D ) ${ }^{4}$.これにより遺伝子 が細胞質に侵入する.アマンタジンはこの侵入の過程 を抑制する化学療法剂である。

3.ザミナビルはウイルス成熟の最終段階をおもに 抑制する。

A．こうして細胞質に入ったウイルスの8本のゲノ 厶遺伝子 (V-RNA) は細胞核内に移動し, ウイルス 自身の持つRNA ポリメラーゼにより転写，複製が同 時に行われるこの際に宿主 m-RNA の $5^{\prime}$ 末端がプラ イマーとして使われる (図 4-3) .
B ．新たに合成されたウイルス蛋白質のうち糖鎖が 付加されるHA,NA,M 2 は粗面小胞体に移行し, 糖鎖 付加され，さらにゴルジ装置で糖鎖修飾を受け，最終 的に細胞の表層に移行する (図 4-4) .

C .ウイルス内部を構成する蛋白質と遺伝子(V-RNA) は細胞質内の表層に移動し (図 4-5), 先の糖鎖結合 蛋白質HA などと集合し子孫ウイルス粒子として 成熟, 細胞外に放出される (図 4-6).この放出の際 にはノイラミニダーゼが関与しており，最近この作用 を阻害するザミナビルが抗インフルエンザ薬として 開発されている. 


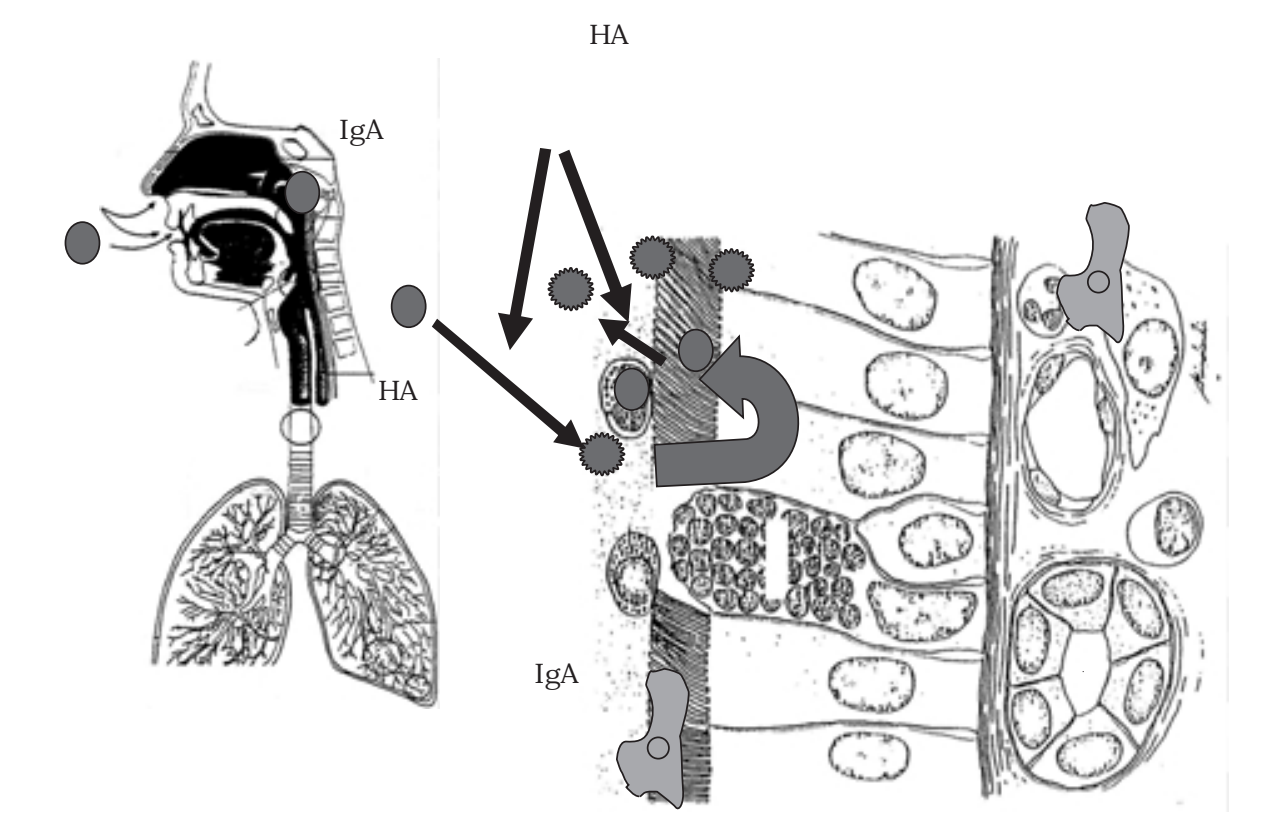

図 2 気道の蛋白質分解酵素によるHA 開裂（文献３をもとに改変）
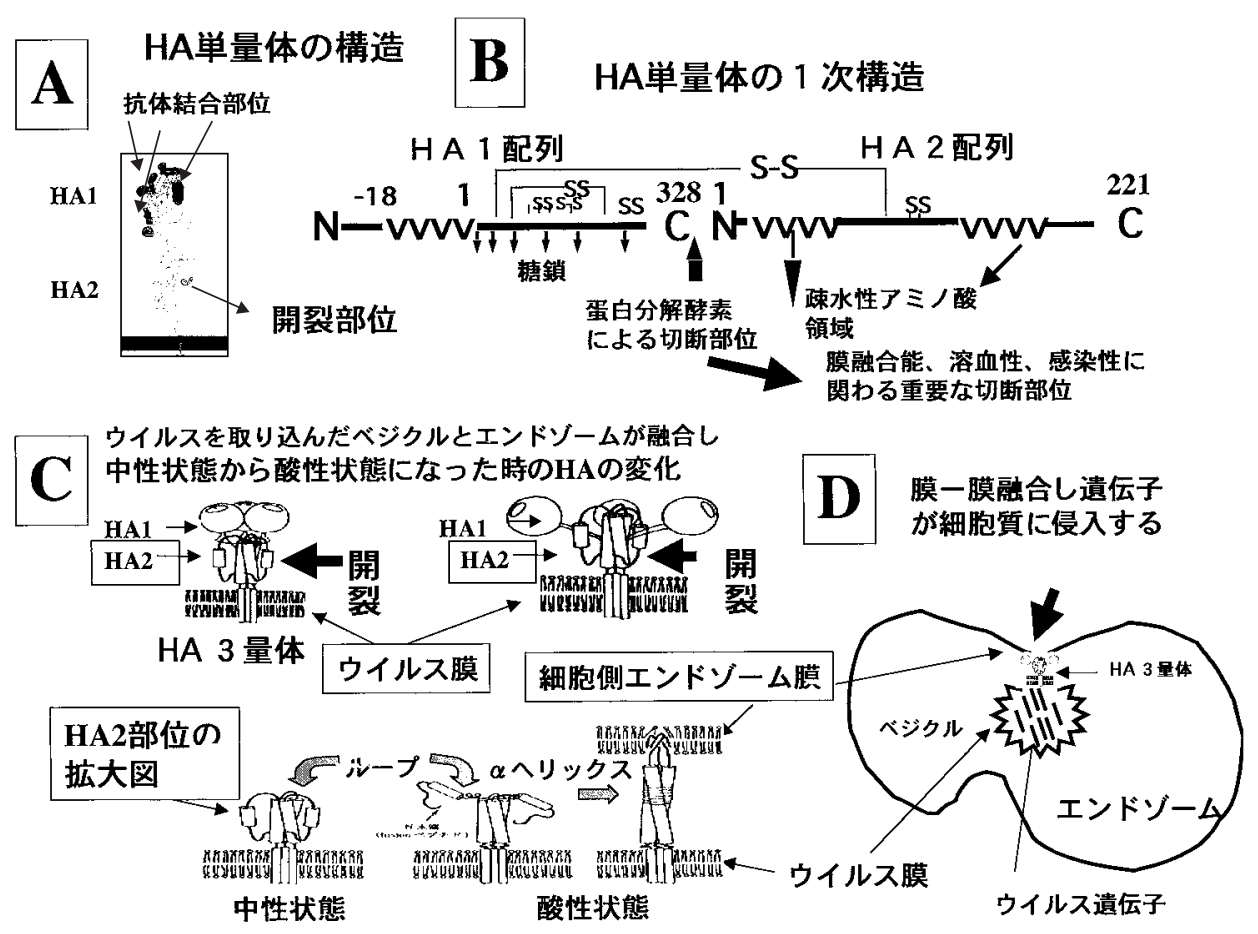

図 3 インフルエンザウイルス遺伝子の細胞内侵入過程と HA 開裂 (文献 4 をもとに改変)

[II ] 個体レベルでの感染 (同じヒトが同じ亜型に反 復感染する)

こうしたウイルスの細胞レベルでの感染に対し , 生体 は免疫防御機構を備えている．しかしながらこれらの 免疫防御機構から逃れたインフルエンザウイルスは 再度ヒトに感染し，毎年流行をもたらす．事実，西川 らは同じヒトが同じ亜型に反復感染していることを報

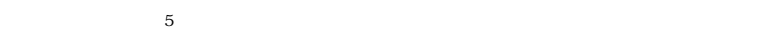
一般に, HA 分子への抗体結合部位は年単位で変異 していくと推論されている.すなわち HA 分子に 対する主要抗体結合部位 (エピトープ) は図 3Aに 示すようにA-E の 5 力所ある .この結合部位の構造 が順次変化していくと仮定すると，5年後に抗体の結 合部位はすべて変化し, 新たなウイルスに感染したと 


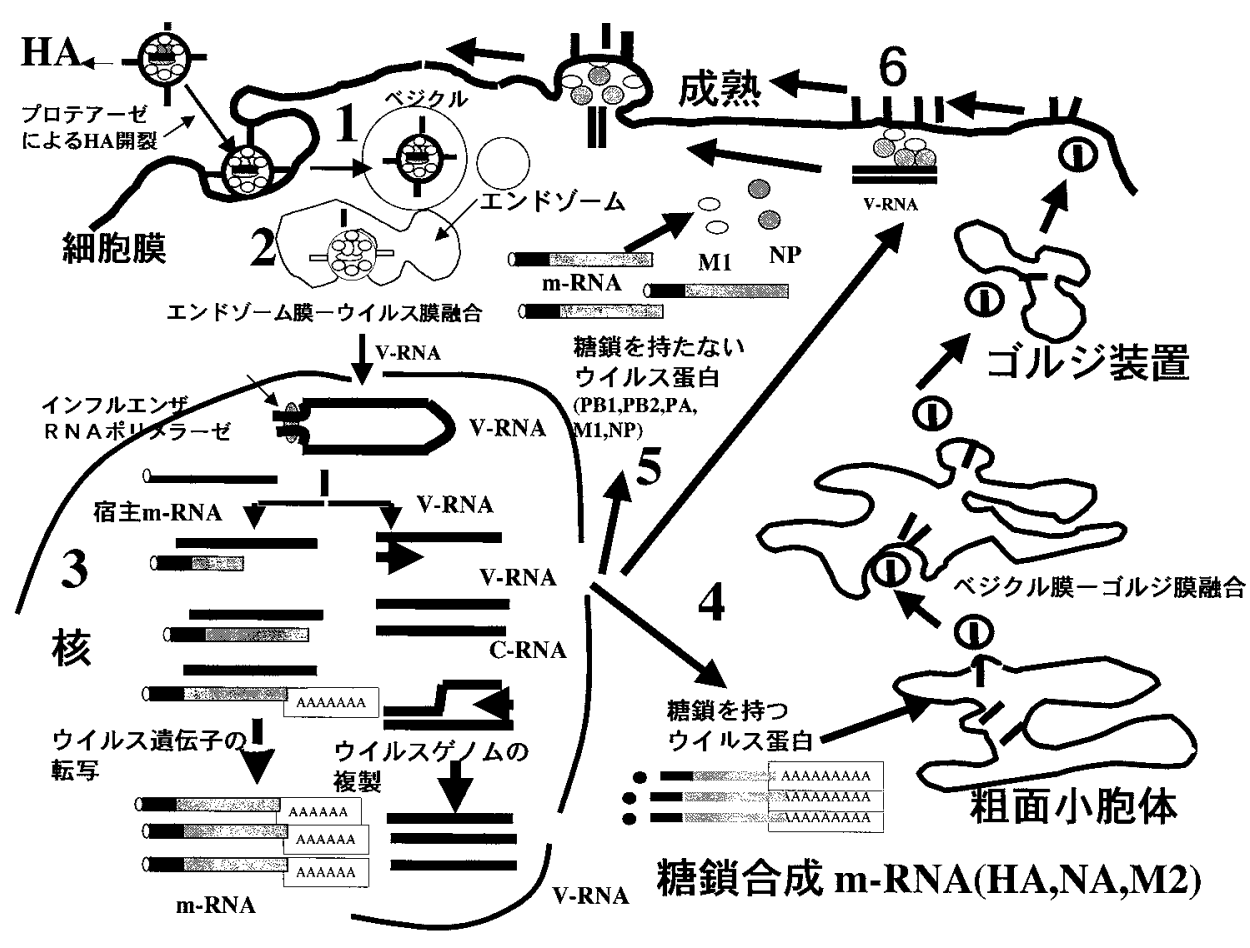

图 4 インフルエンザウイルスの細胞内増殖機構

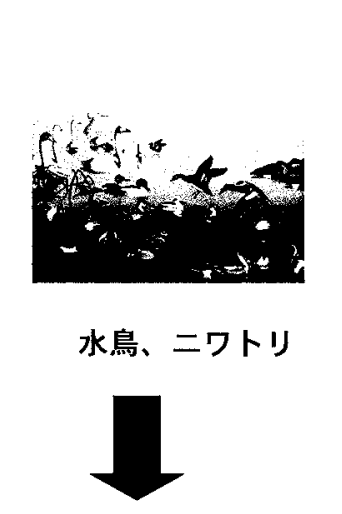

ブタ型インフルエンザ

ウイルス

ヒト型インフルエンザ

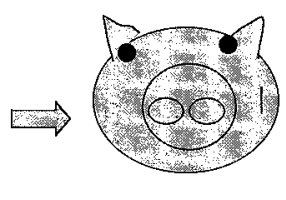

ウイルス

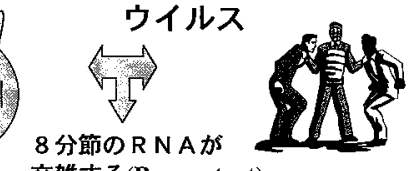

交雑する(Reassortant)

$2^{8}=256$
の組み合わせが可能

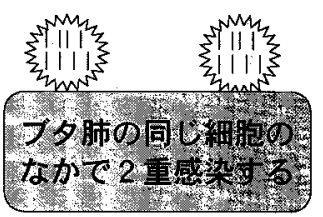

H 5 N 1 （1997年）
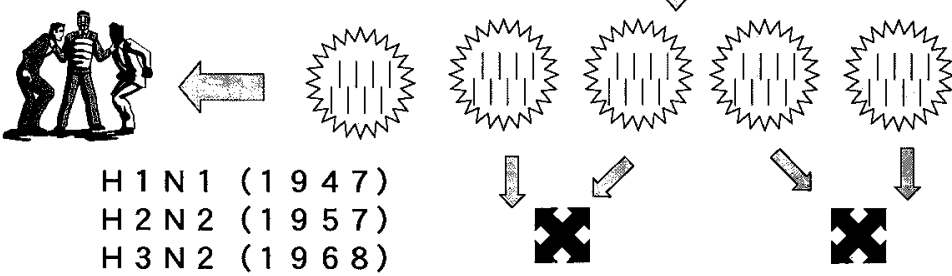

H 1 N $1\left(\begin{array}{llll}1 & 9 & 4 & 7\end{array}\right)$

$\mathrm{H} 2 \mathrm{~N} 2\left(\begin{array}{llll}1 & 9 & 5 & 7\end{array}\right)$

H 3 N $2\left(\begin{array}{llll}1 & 9 & 6 & 8\end{array}\right)$

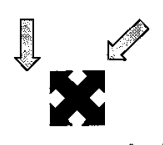

生存に適しない

図 5 インフルエンザウイルスの不連続変異

同じことになる．こうしたウイルスの変異を連続変異 と呼んでいる.しかしながらこの年単位の変異がどこ で起こり蓄積されるかについては，いまだ明らかでは ない .
[III] 個体, 種を越えた感染症としてのインフルエ ンザウイルス

インフルエンザウイルスにはヒト以外にトリ,ブタ， ウマ, クジラ , アザラシなどの動物のインフルエンザ ウイルスがある .これらのウイルスのゲノムは 8本 の断片 (セグメント) からなっていて, ウイルスの 


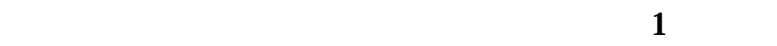
遺伝子断片が他の動物のインフルエンザウイルス遺 伝子断片と交雑し，光の動物種のなかで生存に適した 新たなウイルス (新型ウイルス) として選択されて いく.この過程を不連続変異と呼んでいる (図 5). 喜田らは動物のインフルエンザウイルスの生態につ いて研究を行い, 弚の遺伝子供給源は渡りカモである ことを報告している カモは夏の間は北方圏に生息し， 湖沼水中に大量に存在するウイルスに感染し, 关の腸管 で増殖したのち，粪便とともにウイルスが排泄される . このウイルスに感染したカモは秋にシベリアから南方 に飛来する、南方の中華人民共和国では 水鳥とブタ， ヒトが近接して農業生活を送っており このことが新た なウイルス出現に関係があると喜田らは推論している ${ }^{6}$. こうした不連続変異の例として, 新型トリ型インフル エンザA（H 5 N 1)があげられ，事実このウイルスは 香港周辺からもたらされヒトに感染した .このように インフルエンザウイルスは個体内での変異と動物間で の变異を通して，常にウイルス分化を起こしている.

[IV ] インフルエンザワクチンの研究の現状

こうした個体，種を越えた新たな新型ウイルスの出 現に対応するため，日本および米国ではヒトから分離 された新型 H 5 N 1ウイルスを遺伝子組み換え技術に より弱毒化し , 精製不活化してワクチンとすることが 可能となりつつある. 产のほか現行のワクチンの改良 型として, 発育鶏卵で作るウイルスから組織培養 型へ,低温馴化株の経鼻投与，接種ルートの検討(経鼻， 粘膜投与による分泌型 IgA 産生)，ウイルス核蛋白質 (NP) を発現するプラスミドによるDNA ワクチン， T 細胞活性化をねらったペプチドワクチンなどの研究
がなされている．いずれにしても，我が国における現 行のインフルエンザワクチンの接種率は欧米に比へ極 端に低い．60歳以上の高齢者の場合，ワクチン接種 により罹患率は半減することか報告されており，是非 接種をすべきである . このような変異の激しいウイル スは一回のワクチン接種で終生免疫を得ることは難し いが, 日本で開発が進んでいる粘膜免疫を賦活する噴 霧型不活化ワクチンは今後有効なワクチンとなる可能 性が高いと思われる .

以上, 広く概説したが分子生物学解析, 個体での解析, 集団でのウイルスの生態など特定の階層の理解にかた よらず，階層と階層間におけるダイナミズムの理解と 監視行動が重要であると思われる。

\section{文 献}

1. Cauthien AN, Swayne D, Schultz-cherry SS, Perdue $M L$, Suarez DL:Continued circulation in China of highly pathogenic avian influenza viruses encoding the hemagglutinin gene associated with the $1997 \mathrm{H} 5$ N1 outbreak in poultry and humans. Journal of V irology 2000; 74: 6592-6599.

2. 鈴木康夫 : インフルエンザウイルス宿主域とレセプ ター特異性. 日本臨床 1997; 10: 2640-2647.

3. 田代眞人：インフルエンザウイルス HA 蛋白の開裂 活性化と病原性のメカニズム. 日本臨床 1997; 10: 2633-2639.

4. 大内正信, 大内礼子 : インフルエンザHA の膜融合 活性部位.日本臨床 1997; 10: 2648-2653.

5 . 西川文雄 , 秋田美千代, 中島節子 : インフルエンザの 反復感染について . 臨床とウイルス 2000; 28: 237-247.

6. 喜田 宏 : 動物界におけるインフルエンザウイルスの 生態と新型ウイルス出現のメカニズム.日本臨床 1997; 10: 2521-2524.

(受付: 2002年 2 月 5 日) (受理 : 2002 年 3 月 1日) 